\title{
1950 Seçimleri Sonrası Ulus Gazetesi'nin Muhalefete Geçişi
}

\section{Dr. Alper BAKACAK}

\section{$\ddot{O}_{z e t}$}

1950 seçimleri DP'nin kesin bir zaferi ile sonuçlanınca, iktidardan muhalefete geçen CHP, devlet ile arasındaki bağların varlı̆̆ı dolayısıyla, bu yeni konumunun nasıl bir politik noktada olacă̆ konusunda, kendi içinde yeniden yapılanma ihtiyacı duymuştur. Bu durum CHP'nin yayın organı olan Ulus Gazetesi için de geçerli olmuştur.

İktidarın olanaklarından yoksun kalan CHP'nin, kamuoyuna sesini en etkili bir biçimde duyurabilmesi için, Ulus'a bir önceki döneme oranla daha fazla ihtiyacı olacaktır. Bu durum Ulus'un muhalefet nezdinde değerini arttıran bir unsur olarak karşımıza çıkmaktadır.

Seçimlerin ardından Ulus'un geleceği ile ilgili en önemli gelişme, Nihat Erim 'in gazetenin başına geçirilmesi olmuştur.

Anahtar Kelimeler: Ulus Gazetesi, Cumhuriyet Halk Partisi (CHP), Demokrat Parti (DP) , 1950 Seçimleri, Ismet İönü, Nihat Erim

\section{Abstract}

\section{Elections Post The Ulus Newspaper's Opposition to Pass}

After the results of 1950 elections with DP's ultimate victory, RPP became the opposition party and thus required a reconstruction regarding its new political stance due to the connections with the state. This situation was also valid in the publication organ of RPP, Ulus Newspaper.

In this period of time, RPP, which is deprived of the opportunities of the power, needed Ulus much more than the previous era to be effectively noticed in the public

\footnotetext{
*Ankara Üniversitesi Türk İnkılap Tarihi Enstitüsü Öğretim Görevlisi.
} 
opinion. At this point, Ulus became the factor having increased its value by the opposition.

The most important development about the future of Ulus after the elections was appointment of Nihat Erim as the director of the newspaper.

Key Words: The Ulus Newspaper, Republican People's Party, Democratic Party, 1950 Elections, İsmet İnönü, Nihat Erim.

\section{Giriş}

1923'de "Halk Firkası" adıyla kurulmasının ardından y1llar süresince Türk siyasal hayatında "tek parti" olarak devlete eklemlenmiş bir yapıya sahip olan Cumhuriyet Halk Partisi (CHP), Demokrat Parti (DP)'nin 1946'de kendi içinden kopan kadrolarca kurulması sonrası yeni bir döneme girmiştir. "Demokratikleşme" talepleri içeren bir söylem üzerinden politika yapmaya başlayan DP'nin giderek güçlenmesi ile iki parti arasında gerilim temelli bir ilişki oluşmaya başlamış, Cumhurbaşkanı İsmet İnönü’nün 12 Temmuz 1947'de yaptığ 1 ve tarafsız bir konum alacağını belirten konuşması da bu durumu değiştirmek yönünde pek etkili olamamıştır. Sonraki yıllarda CHP'nin demokratikleşme yolunda attığı adımlara rağmen 14 Mayıs 1950 genel seçimlerine bu gerilimli hava ile girilmiştir.

1950 seçimlerinin DP'nin kesin zaferi ile sonuçlanması sonrasında iktidardan muhalefete geçen CHP, devlet ile arasındaki bağların varlığı dolayısıyla bu yeni konumunun nasıl bir politik noktada olacağ kendi içinde yeniden yapılanma ihtiyacı duymuştur.

CHP'deki yeniden yapılanma ihtiyac1, partinin her alanında hissedilmiştir. Buna yayın organı olan Ulus Gazetesi de dahildir. Kuruluşu 10 Ocak 1920 tarihinde gerçekleşen ve zaman içinde CHP'nin yayın organı haline gelen, (bir önceki adı ile "Hakimiyet-i Milliye") Ulus Gazetesi'nin de bu yeni dönemde yapısında gözle görülür bir değişim yaşanacak mıdır? $\mathrm{Bu}$ değişim partideki siyasi ya da örgütsel bir değişime paralel olarak m1 gerçekleşecektir? Yoksa sadece gazetenin söyleminde mi farklılıklar oluşacaktır? CHP'nin Meclis'teki milletvekili sayısı göz önünde tutulursa, meclis dış1 muhalefetin önem kazanması, Ulus'a bu dönemde yapacağı görev konusunda daha da büyük sorumluluk verdiği söylenebilir mi?

$\mathrm{Bu}$ bağlamda Ulus'ta yaşanan değişiklikler ve kurulacak yeni düzen, CHP'nin politikalarını da doğrudan etkileyebilecek olması muhtemeldir. Muhalefete geçişle birlikte gazetenin daha önceki misyonu olan "CHP'nin icraatlarını "muhalefete karşı savunma"”nın yerini, on yıl sürecek olan "DP 
iktidarına karşı en sert muhalefeti yapan gazete" olma kimliğine bürünecek olan Ulus'un, kendi kurumsal tarihi açısından, Atatürk dönemi ve İnönü döneminden sonra tarihindeki üçüncü döneme yani muhalefete geçişinde yaşanan tartışmalar bu makalede yukarıda değinilen sorular çerçevesinde incelenecektir.

\section{Seçimleri ve Sonrast}

14 Mayıs 1950 seçimlerinin resmi olmayan sonuçları CHP'nin artık iktidarda olmadığı gerçeğini ortaya çıkartmıştır. 16 Mayıs 1950 günkü Ulus'un manşeti de bu gerçeği ortaya koyarak, gazetenin artık bir "muhalefet gazetesi" olduğunu dile getirmektedir. Manşet şu şekilde çıkmıştır: "Milletimizin verdiği karar Pazar günkü seçimde tecelli etti. CHP iktidarı denetliyor, CHP meclisin içinde ve dişında tam bir muhalefet ve tenkit partisi olarak vazifesine devam edecektir." $\mathrm{Bu}$ başlıkta dikkat çeken iki nokta olduğu söylenebilir. Seçimler ile gelinen bu durumun "milletimizin kararı" olduğu vurgulanarak demokratik ilkeler uyarınca bu tercihin meşruluğu tartışılmaksızın kabul edilmiştir. Bir diğer nokta ise muhalefet ve eleştiri işinin, Meclis'in içinde CHP milletvekillerince yapılacağı, dışarıda ise Ulus Gazetesi'nin de içinde olduğu parti örgütü tarafından yürütüleceği açıkça vurgulanmıştır.

Artık, iktidarın olanaklarından yoksun kalan CHP'nin kamuoyuna sesini en etkili bir biçimde duyurabilmesi için Ulus'a bir önceki döneme oranla daha fazla ihtiyaci olacaktır. Bu durumda Ulus, muhalefet nezdinde değerini arttıran bir unsur olarak karşımıza çıkmaktadır. Ancak yeni dönemde Ulus için işlerin bir önceki döneme oranla daha zor geçeceği kesindir.

Aynı gün, gazetenin başyazısında ise, Ulus'un başyazarı sıfatına sahip olan duayen gazeteci Hüseyin Cahit'in imzasıyla, "Büyük İsmet İnönü" başlıklı makaleye yer verilmiştir. Büyük başarı göstererek seçimleri kazanan DP'lileri tebrik eden yazar, dış politikaya dikkat çekerek, dünyanın siyasi bir karmaşa içinde olduğu bir dönemde, Türkiye'de iktidarın değiştiğini saptadıktan sonra, şöyle devam etmektedir: ${ }^{2}$

"Vatanımızın düşmanlarının memleketimizdeki hükümet değişikliğinden dolayı sevinmeye imkân bulamayacaklardır. Çünkü Demokrat Parti öteden beri dış politikada Halk Partisi siyasetiyle mütesanit [danışıklı] yürüyordu. Şimdi Halk Partisi, Demokrat Hükümetinin dış siyasetinde kendisine kuvvetle

\footnotetext{
${ }^{1}$ Ulus, 16 Mayis 1950.

${ }^{2}$ Hüseyin Cahit Yalçın,“Büyük İsmet İnönü”, Ulus, 16 Mayıs 1950.
} 
müzaharet [yardım] gösterecektir. Bu bakımdan düşmanımıza karşı tek bir müdafaa ve mukavemet cephesi vücuda getirmek hususunda memlekette hiçbir değişiklik olmayacaktır"

$\mathrm{Bu}$ yazıda dikkat çeken diğer bir ayrınt1, "Stalin totalitarizminin" etkisindeki Sovyetler Birliği ve ona siyasal olarak bağlı Doğu Avrupa ülkelerini’nin “düşman” olarak nitelendirilmesidir.

İsmet İnönü'nün adının geçtiği bir başlığa sahip olan bu başyazıya, öncelikle dış politikanın irdelenerek başlanması DP ile CHP'nin ortak noktalarının tespit edilmesine olanak sağlaması bakımından ilgi çekicidir. İktidarının ilk dönemi olan 1950-1954 yılları arasında yaşanan dış politik gelişmelerde çeşitli küçük farklar dışında, DP ile CHP'nin ve tabii Ulus'un paralellik göstermesinin kaçınılmaz olduğu söylenebilir. Daha sonraki süreçte de görülmesi muhtemel olan bu politik ortak paydanın seçim sonuçlarının henüz açıklandığı çok erken bir dönemde ortaya konulması ve bunun altının net bir biçimde çizilmesi, üzerinde önemle durulması gereken bir durumdur.

Sıra iç politikaya gelince yazarın ilk beklentileri yine olumludur. Yazar, "Her demokratik memlekette olduğu gibi" normal koşullar içinde kalarak siyaset alanının devam edeceği düşüncesindedir. Yazısının sonlarına doğru ise yazar başlıkta adı geçen, İsmet İnönü'ye değinmektedir. Öncelikle demokratik usullere uygun şekilde yaşanan iktidar değişikliğini bir devrim olarak algılayan Yalçın, bu devrimin İnönü sayesinde gerçekleştiğini şu cümlelerle ortaya koymaktadır: ${ }^{3}$

"Atatürk demokratik inkllâbın temelini attı, heykelini yükseltti. İsmet Inönü o heykele can verdi. Bir diktatör salahiyetiyle Cumhur Başkaniliğına gelen İsmet İnönü yalnız kendi vicdanından ve irfanından aldiğ emre uyarak milli hakimiyet cihazın harekete getirdi. Şimdi milletin iradesi karşlsinda memleketin kanununa her fert gibi pek tabii surette boyun eğerek alelade bir vatandaş sifattyla siyasi mücadelede yerini alıyor. Tarihte mislini hatırlamadiğımız bu ulvi hareketin bir Türk devlet adamı tarafindan medeniyet tarihine hakkedilmiş olması milli bir şereftir... İnönü'nün memlekete yapacă̆ hizmetler daha bitmemiştir. Bir demokratik rejimin nasıl kurulacağını, nasıl işleyeceğini bize gösterdiği kadar ciddi, şuurlu ve vatansever bir muhalefetin nasil vazife göreceğini de bize o ögretecektir."

\footnotetext{
${ }^{3}$ A.g.m, Ulus, 16 Mayıs 1950
} 
Artık saflar netleşmiştir. Beklenilenin tersine CHP ve Ulus muhalefet etmenin erdemini ön plana çıkararak yeni döneme geçişi başlatmıştır. 20 Mayıs'ta İnönü, CHP'nin Genel Başkanlığını fiilen ele almış, böylece ilk kez eski bir Cumhurbaşkanı, muhalefet lideri olmuştur. Ancak kurumsal olarak Ulus Gazetesi için belirsiz bir dönem de başlamıştır. Gazeteciliğe Ulus'ta başlarken başından geçenleri anlattığı anılarında Altan Öymen, CHP'nin önemli isimlerinden olan babasının (Hıfzırrahman Raşit Öymen) Ulus'un geleceğinin henüz netlik kazanmaması dolayısıyla bu gazetede çalışmasına sicak bakmadığını anlatır ${ }^{4}$.

\section{Ulus'ta Nihat Erim Dönemi'nin Başlaması}

Ulus'un geleceği ile ilgili en önemli gelişme Nihat Erim'in 21 Mayıs 1950'de gazetenin başına geçirilmesi olmuştur.

Ankara Hukuk Fakültesi hocalarından olan Nihat Erim, 1945 yapılan ara seçimlerde CHP'den milletvekili olarak politik hayata adım atmış, Cumhurbaşkanı İnönü'nün ünlü 12 Temmuz (1947) Beyannamesi sonras1 yaşanan kabine değişikleri döneminin reformist, genç ve dinamik politikacılardan biri olarak ön plana çıkmaya başlamıştır. II. Hasan Saka kabinesinde Bayındırlık Bakanlığı yapmış sonrasında kurulan Şemsettin Günalatay hükümetinde ise Başbakan Yardımcısı olmuştur. ${ }^{5}$

Aynı günlerde Ulus Gazetesi'nin de bu siyasal değişim sürecinde benzeri bir değișim geçirmesi sözkonusudur. Gazete, CHP'deki reformist kanadın hâkimiyetine bu dönemde girmeye başlamıştır. $\mathrm{Bu}$ durumun etkisiyle, 1945 'den beri zaman zaman yazıları yayımlanan Nihat Erim'in, gazetenin kıdemli başyazarı Falih Rıfkı Atay ile beraber 1947 yılı ortalarından itibaren başyazarlık görevini dönüşümlü olarak üstlendiği görülür. ${ }^{6}$ Hüseyin Cahit Yalçın'ın 1948'den itibaren Ulus'da yazmaya başlaması, Falih Rıfkı'nın gazetedeki ağırlığının giderek azalmasına neden olmuş, 1950 seçimleri sonrası gazeteden tamamen kopması ile sonuçlanmıştır. Erim, hem Yalçın hem de Falih Atay'ın yanında gazetecilik ile ilgili tecrübesizliğini atmış olarak ve İnönü’ye yakınlığının da verdiği güçle, CHP muhalefet dönemine geçerken tek yetkili olarak Ulus Gazetesi'nin başına geçirilmiştir.

\footnotetext{
${ }_{5}^{4}$ Altan Öymen, Değişim Yılları, İstanbul, Doğan Kitapları, 2004, s. 502. 61 ve 68

Süleyman Coşkun, Türkiye'de Politika (1920-1995), İstanbul, Cem Yayınevi, 1995, s.

${ }^{6}$ Hürriyet Konyar, Ulus Gazetesi, CHP ve Kemalist İlkeler, İstanbul, Bağlam Yayınları, 1999, s. 15.
} 
Nihat Erim anılarında bu göreve getirilişini şu şekilde aktarmaktadır: ${ }^{7}$

"16 Mayıs günü saat 11'de Başbakanliğa gittim. Başbakan'ın [Şemsettin Günaltay] yanında Vedat Dicleli vardl. Biraz sonra İnönü geldi. O gelmeden başbakan bana şu haberi verdi: 'Dün akşam İnönü, seni Ulus gazetesinin başına geçireceğini söyledi. Ben itiraz ettim, 'parti idaresi tamamen değişmedikçe Nihat'ı oraya getirmek, onu da Falih Rıfkı gibi antipatik yapar. İşi esasindan halletmeli' dedim. Sakın kabul etme' dedi.

Ben cevap verdim: 'İnönü parti başkanliğını fiilen ele alsın. O zaman yalnız onunla çalışmak üzere kabul ederim.'

Erim, günlüğüne 22 Mayıs 1950 tarihinde ise şu notlart düşmüştür: ${ }^{8}$

"Dün İnönü beni parti merkezine çağırdl. H.Uran ile yalnız idi. Ulus gazetesi için çağırtmış. 'Kurultay toplanmadan bugünkü şekil değiştirilmeyecek. Kurultaya kadar bu şekli muhafaza edilsin. Sen yazı işlerini murakabeyi kabul et' buna cevaben 'paşam siz üzülmeyin, ne vazife verirseniz yaparım' dedim... Ulus'un mali ve idari işlerinin başına İsmail Rüşı̈̈ Aksal'’ getirmesini söylemiştim. Tekrar hatırlattım... H. Uran da beni destekledi. 'Naşit Hakkı'yı Ulus'tan uzaklaşstrmalı, onun yerine İsmail'i koymalı' dedi. İnönü uygun buldu...

Dr. Ahmet [Selgil], Cemil Barlas, Dr. Kemal Satır ayrı bir hizip halinde Ulus'un kendi ellerinde kalmasin istiyorlar. Benim Ulus'un başına geçmemi istemiyorlar. Mümtaz Ökmen takımindan başka bir de bunlar var."

Yukarıda altını çizdiğimiz gibi Nihat Erim'in Ulus'un başına getirilmesinin parti içinde bazı isimlerin muhalefetine rağmen olduğu söylenebilir. Faik Ahmet Barutçu anılarında, partinin önemli isimlerinden Avni Doğan ve Şemsettin Günaltay'ın İnönü'ye haber gönderip, bu konudaki rahatsızlıklarını ilettiklerini, Doğan'ın bu durumdan dolayı kurultayda bazı karışıklıklar, hatta bölünmelerin bile yaşanabileceğinin İnönü’ye iletilmesini istediğini, bu tepkilere rağmen İnönü’nün "biz kaybedeceğimiz kadar kaybetmişiz. Bizden şu ya da bu ayrılacak diye düşünemeyiz" diyerek Erim'in arkasında durduğunu aktarmaktadır.'

\footnotetext{
${ }^{7}$ Nihat Erim, Günlükler 1925-1979, C.I, İstanbul, YKY, 2005, s. 449.

${ }^{8}$ Erim a.g.e..,s. 453.

${ }^{9}$ Faik Ahmet Barutçu, Siyasi Anılar, İstanbul, Milliyet Yayınları, 1977, s. 434-435.
} 
Bu kadar tepkiye rağmen İnönü'nün Erim ile çalışmak istemesinin nedeni ise Erim'in yazı yazmadaki yeteneği ile ilişkilendirilmektedir. Öymen, Barutçu'nun ağzından şu anıyı paylaşmıştır:

"Ben [Barutçu] paşanın evindeyim... Paşa Nihat'ı çağırdı. Ulus'a yazllacak yazının mevzuunu verdi. Yarım saat içinde Erim yazıyı hazırladı. Bu kadar sühuletle (kolaylıkla) yazı yazan adam nadir gördüm. Yanımızda tashihsiz (düzeltmesiz) dört beş kağıt doldurdu. Bir kelimesini değisstirmeye ihtiyaç hâsıl olmadl. 'Haydi sen git Ulus'a tertiple (düzenle)' diyerek Nihat'l gönderdi.

\section{Bana döndü. Dedi ki:}

'Bir fikir verdik, görüyor musun ifadeye nasıl muktedir oluyor; klymet değil mi?",

Böylece Nihat Erim gazetenin politikasını tek başına belirleyen kişi konumuna gelmiştir. Hüseyin Cahit Yalçın'ın yazmadığı günlerde, başyazı onun imzası ile çıkacaktır. Erim, 1950 öncesinden kalma parti içindeki etkinliği düşünüldüğ̈̈nde kamuoyunda "İsmet Paşa'nın fikir ve düşüncelerinin aynası" olarak görülecektir. Ancak Metin Toker bu durumun şu şekilde olduğunu belirtmektedir: "1950 öncesinde daha çok, 1950 sonrasinda daha az"."

Yönetimi değişen Ulus Gazetesi, Meclis'in açılması ve hükümetin kurulması aşamasında, özellikle bir önceki dönemden yeni döneme geçişte, neredeyse hiçbir sorunun aktarılmadığının altını çizerek, yeni hükümetin zorlanmadan işe başlayabileceğini vurgulamaktadır. Bu konu ile ilgili başyazısında Hüseyin Cahit, Ulus'un muhalefet yapma hakkını saklı tutarak "silahlarını teslim etmiş ümitsizliğe ve yasa dışı lakayt bir seyirci kalmak kararını vermiş zannedilmemelidir" demektedir. Yazar böylece, muhalefetin bir kontrol vazifesi olduğunun üzerinde durarak ülkenin çıkarlarının kendi hak ve yetkileri içerisinde savunulacağını bu şekilde ortaya koymaktadır. ${ }^{11}$

Her ne kadar kararlı bir şekilde muhalefet edecekleri izlenimi verilmeye çalışılsa da, DP'nin idareyi ele aldığı günlerde Ulus, özellikle yumuşak denebilecek bir üslup kullanmaktadır. ${ }^{12}$ Eleştiriye ağırlık vermek yerine, dışa karşı CHP'nin gücünü yitirmediği imajı çizilmeye çalışılmıştır. Özellikle partinin nasıl bir ruh halinde olduğu üzerinde durulmuştur. Ulus'ta çıkan

\footnotetext{
${ }^{10}$ Metin Toker, DP'nin Altın Yılları, Ankara, Bilgi Yayınevi 1991, s.75.

${ }^{11}$ Hüseyin Cahit Yalçın, "Yeni İktidar", Ulus, 22 Mayıs 1950.

${ }^{12} \mathrm{Bu}$ duruma örnek olabilecek manşetler için bkz. "B.Millet Meclisi Bugün Çalışmalara Başlıyor” Ulus, 22 Mayıs 1950, "Demokrat Parti İktidarı Fiilen Ele Aldı”, Ulus, 23 Mayıs 1950. Bu örnekler çoğaltılabilir.
} 
çeşitli haber ve yorumlarda CHP'nin herhangi bir matem havasında olmadığı, hatta parti içinde "teessür ve infial" gibi duygulara hiç yer olmadığı sıkça vurgulanmaktadır. Ulus'un önemle, CHP'de yapısal bir kriz olmadığına kamuoyunu inandırma yönündeki gayretlerine rağmen, mevcut durumun gerçekte ne olduğu olağanüstü kurultayda ortaya çıkmıştır.

Aynı günlerde gazetenin sorumlusu ya da patronu konumundaki isim olan Nihat Erim'in 25 Mayıs'ta başlayan bir yazı dizisi üzerinde durmak yerinde olacaktır. "Demokrasi Yolunda Bir Oluşun Hikâyesi" adıyla 11 gün yayımlanan bu yazı dizisinde, 1945 yılının ikinci yarısından sonra 14 Mayıs 1950’ye kadar geçen beş yıllık dönemin bilânçosu çıkarılmıştır. Bu yazı dizisi, daha önce de Hüseyin Cahit Yalçın'ın yazılarında da olduğu gibi İsmet İnönü'nün demokrasiye geçişteki önemi üzerinde durarak bitmektedir. ${ }^{13}$

“ 'Bütün bunları İönü mü yaptı?... Millet yaptı' diyenler varmiş. Elbette her şey Türk Milletinin müstesna yaradılışı, kabiliyetleri, yeniliğe ve ilerlemeğe olan istidad [yeteneği] sayesinde tahakkuk etmiştir. Fakat unutulmamak lazım dır ki milletler hasletlerini ne olursa olsun başta iyi ve ya fena liderler bulunduğuna göre saadet veya felakete uğrarlar. Yirminci yüzyllın ilk yarısında Türk Milleti iki büyük lider yetiştirmişstir... Bizlere mütesanit bir diktatörle değil, kahramanların kahramanı bir vatan ve millet büyüğ̈̈ ile birlikte çalışmanın şeref ve zevkini tattıran İnönü'ye hayranlık ve minnetim sonsuzdur."

Aynı günlerde CHP'nin yeni dönemi için ilk toplantı da yapılacaktır. 27 Mayıs 1950'de düzenlenen bu toplantı Parti Divanı'nda gerçekleştirilmiştir. CHP'nin seçimler sonrası nasıl bir politika izleyeceğinin sinyalini vermesi bakımından önemi büyük olan toplantıda İnönü, Genel Başkan sıfatıyla CHP'nin bu yeni dönemdeki politika hedeflerini ortaya koymuştur. ${ }^{14}$

İnönü yaptığ 1 konuşmada, CHP'nin kaybetmesinin nedenlerini değerlendirirken, birçok sahada yürütülen bir mücadeleye vurgu yapmış, bunların arasında özellikle geçmişten beri biriken tepkilerin oluşturduğu "sinsi" çalışmalara dikkati çekmiştir. Gelinen bu aşamada parti örgütü ve partililere düşen görevler olduğunu vurgulamış ve bu görevleri dört bölümde tanımlamıștır. Bunlardan ilki; CHP örgütü ve CHP'lilerin parti adına yürütecekleri faaliyetlerde iktidar tarafından herhangi bir baskı altında kalmayacaklarına güvenmelerine yönelik hareket etmek olmuştur. $\mathrm{Bu}$

\footnotetext{
${ }^{13}$ Nihat Erim, "Demokrasi Yolunda Bir Oluşun Hikayesi XI”, Ulus, 5 Haziran 1950.

14 Süleyman Güngör, Muhalefette Cumhuriyet Halk Partisi, Ankara, Alternatif Yayınlar1, 2004, s. 82.
} 
aşamada iktidara da görev düşmektedir. CHP'nin beklentisi, bir önceki dönemdekine benzer şekilde, muhalefetin var olabilmesinin güvenlik koşullarının yerine getirilmesidir. Çok partili bir siyasal hayatta muhalefetin doğal bir durum olduğunu vurguladıktan sonra, parti yerel yöneticilerinin, memleketin en ücra köşelerine kadar giderek, CHP sempatizanlarına başlarına herhangi bir şeyin gelmeyeceğine dönük güvence vermelerini istemiştir. İnönü'nün bu konuşmasında vurguladığı ikinci görev ise CHP'nin iktidardan ayrılmasından sonra bile partiye yönelik saldırılardan kurtulamayacağının bilinciyle hareket edilip, buna hazırlıklı olunmasıdır. $\mathrm{Bu}$ saldırıları İkinci Dünya Savaşı'ndan arda kalan “sinir harbi”ne bağlayan Genel Başkan, CHP örgütünden bu gergin durumu devam ettirecek olan gazetelerin, broşürlerin ve ajansların partinin aleyhine yönelik faaliyetlerini fark etmelerini istemiştir. Üçüncü görev ise muhalefet görevinin bir olumsuzluk olmadığının tam tersine yüceltilmesi gereken "şerefli" bir durum olduğunun altının çizilmesidir. Demokratik rejimin Türkiye'de kökleşmesi için "yapıcı" bir muhalefet anlayışına ihtiyaç olduğu ve bunu da CHP'nin yapacağını vurguladıktan sonra dört sene sonraki seçimlere kadar seçmenin kararının bekleneceğini söylemiştir. Dördüncü ve son görev olarak ise, partililerinden yeni dönemde de tıpkı iktidardaymış gibi memleket çıkarlarını ve güvenliğini gözetmek konusunda hassas olmalarını istemiştir. ${ }^{15}$

İnönü’nün bu konuşmasında altını çizdiği görevler doğrultusunda Ulus Gazetesi'nin de önemli bir konumu olduğu açiktır. Öncelikli olarak CHP yandaşlarına özgüven aşılayacak şekilde yayınlar yapılması gerekmektedir. $\mathrm{Bu}$ yapılırken iktidar partisine karşı muhalefetin çok önemli olduğu ve demokrasinin muhalefetin varlığının güvencede olmasıly orantılı olarak yerleşebileceği vurgulanmaktadır. Muhalefette olmanın erdemi üzerinde durulması ve bunun doğal bir şey olduğunun halka benimsetilmesi gerekmektedir. Bu açıdan bakıldığında yukarıda da görüldüğü gibi Ulus'un bu ilk aşamadaki yayımlarında, neredeyse tamamıyla, İnönü ve onun erdemlerinden bahsetmesi yersiz değildir.

\section{CHP'nin 8. Kurultayt ve Ulus Gazetesi}

Seçimlerin hemen ardından alınan yenilginin analizi konusunda içe kapanan bir anlayış sergileyen CHP'nin esas tartışmayı yaklaşmakta olan Kurultaya sakladığı anlaşılmaktadır. Yukarıda da değinildiği gibi Ulus Gazetesi, CHP'de herhangi bir paniğin ya da yılgınlığın yaşanmadığının, geçmişte de eleştirilmesine neden olacak herhangi bir durumun olmadığının ısrarla altını çizmeye gayret ettiğini görebiliriz.

\footnotetext{
${ }^{15}$ Güngör, a.g.e.,s. $82-83$
} 
Aynı günlerde CHP'yi zor duruma sokabilecek başka tartışma başlıkları da gündeme gelmiştir. Bunlardan biri İsmet İnönü'nün büyük oğlu Ömer İnönü'nün adının, ölümle sonuçlanan bir araba kazasına karışması, bir diğeri ise Halkevleri'nin CHP'den alınarak devlete devri gibi konulardır. Bu konular DP'nin milletvekillerince gündemde tutulmaktadır ve böylece "hesap sorma" fiilen başlamış bulunmaktadır.

Böyle bir ortamda 29 Haziran 1950 tarihinde CHP'nin 8. Kurultayı Ankara'da toplanmıştır. Ulus Gazetesi, İnönü "çok önemli bir nutuk söyleyecek" başlığıyla kurultayı duyurmuştur. Haber "Halk Partisinin tarihi içinde hususi bir mevki işgal edecek olan Sekizinci Büyük Kurultayın memleketimiz ve Partimiz için hayırlı ve verimli kararlarla sona ereceğinden şüphe etmediğimiz çalışmalarda muvaffakiyetler dileriz" şeklinde yer almıştır. CHP delegelerinin hemen hepsinin Ankara'ya geldiği, kongreyi izlemek isteyen yüzlerce kişinin giriş kartı almak için partiye başvurduğu haberleri de yine Ulus'un 29 Haziran 1950 tarihli sayısında yer almaktadır.

Gerçekten de beklenildiği gibi 8. Kurultay daha önceki kurultaylara hiç benzemeyecektir. Seçimlerin öncesinde listelere giremeyen milletvekillerinin istifaları ile başlamış olan parti içindeki huzursuzluk, seçimlerde yaşanan "beklenmeyen" başarısızlıkla daha da artmıştır. Bunların dışında sıradan üyelerin de istifaları gelmiştir. Ulus, bazı istifalardan hiç söz etmemiş̧tir. Sadece ayrılanlara yönelik eleştirel yazılar gazetede yer almıştır. Bu sayede eleştirilen kişinin CHP'den ayrıldığı anlaşılabilmektedir. ${ }^{16}$

Bu ortamda Ankara Halkevi'nde toplanan kurultay hiç olmadığı kadar delege ağırlıklı gerçekleşmiştir. Önceki kurultaylarla karşılaştırıldığında milletvekilleri için ayrılan bölümün azlığ 1 dikkat çekici olmuştur. ${ }^{17}$ Belki de asıl dikkati çeken durum İnönü'nün Genel Başkanlığı'nın tartışılır hale gelmiş olmasıdır. Kurultay öncesinde bir grup partili, partinin yeni bir solukla gençleşmesi için İnönü'nün Genel Başkanlığı bırakması gerektiği düşüncesindedir. ${ }^{18}$

İnönü ise 14 Mayıs seçimleri ile iktidarını yitirmesi ile panik havası yaşanmakta olan CHP'nin başından ayrılmayarak bu moral bozukluğunu dağıtmak yönünde hareket edecektir. İnönü'nün hedefi partide birliği sağlamak, Cumhuriyeti kurmuş ve Atatürk'ün öncülük etmiş olduğu devrimleri yapmış partiye uygun düşecek şekilde ana muhalefet rolünü

\footnotetext{
${ }^{16}$ Güngör, s. 184.

${ }^{17}$ Hikmet Bila, Sosyal Demokrat Süreç İçinde CHP ve Sonrası, Milliyet Yayınları, 2. bask1 1987, s. 194.

${ }^{18}$ Feroz Ahmad, Demokrasi Sürecinde Türkiye (1945-1980), Çev. Ahmet Fethi,

İstanbul, Hil Yayın, 1996, s. 110.
} 
yerine getirmek olarak karşımıza çıkacaktır. ${ }^{19}$ Ancak bir önceki döneme göre imajının büyük bir darbe aldığı da ortadadır.

Ulus Gazetesi ise bu süreçte İnönü'ye tam destek vererek, onun kararlarını desteklediğini ve hedeflerini gerçekleştirmesi için ona ihtiyaç duyulduğunu ifade eden yazılar yayımlamaya devam etmiştir. Ulus'un 30 Haziran sayısında ilk sayfada yer alan haber İnönü’ye verilen desteği ortaya koyması bakımından önemlidir. "İnönü’ye sevgi tezahürleri” başlıklı habere göre Meclis binasından çıkıp Halk Partisi binasına gelinceye kadar halk, İnönü'yü "coşkun tezahüratla" selamlamış, "yaşa, sen çok yaşa" diye alkışlamıştır. "Bu sırada yaşlı bir vatandaş da İnönü’nün yanına sokularak hem ağlamış hem de 'Paşam sen üzülme, biz senin için canımızı feda ederiz' demiştir." İnönü'nün de vatandaşların bu sevgi gösterilerine onları selamlayarak yanıt verdiği de yazıya ilave edilmiştir. ${ }^{20}$

Aynı gün Nihat Erim'in "Partimiz ve Kurultayımı" başlıklı yazısı birinci sayfada yayımlanmıştır. Erim bu yazısında, CHP'nin Atatürk ve İnönü dönemlerinde iktidarda yaptıklarını överken, muhalefet döneminde de henüz iki ay geçmesine rağmen CHP'den hesap sorulmasını, Halkevlerinin devredilmesi gündeme gelmesini eleştirmektedir. "Başkan" diye seslendiği İnönü'nün şahsı ve ailesi ile uğraşılmaya başlandığına dikkat çekerek, yaşanan bu olayların CHP'nin kendisinden son derece emin olmas1 gerektiğini gösterdiğine işaret etmektedir. ${ }^{21}$

Kurultay çalışmalarının en canlı şekilde devam ettiği günlerde, yukarıda belirtilen farklı konuların ortaya çıkması göz önünde tutulduğunda, ister istemez Ulus'un gündeminin sıkıştığını gözlemleyebiliriz. Ancak yine de, Ulus sütunlarında Kurultayın ayrıntılarının daha çok yer tutması, diğer konuların ise göreceli olarak daha az işlenmesi söz konusu olacaktır.

Kurultay çalışmaları ise beklenenden farklı olarak renkli geçmektedir. 100'den fazla delegenin, hazırlayıp imzaladıkları bir broşürle parti tüzüğünde ve parti programında köklü değişiklikler talep etmişlerdir. Bu delegelerin muhalif şekilde harekete geçmelerine rağmen, oybirliği ile yeniden Genel Başkan seçilen İnönü'nün araya girmesi ile sadece parti tüzüğünde bazı değişiklikler yapılmıştır. ${ }^{22}$ Ancak reforma duyulan ihtiyaç göz önünde tutularak, Genel Başkan'1n eski gücünün devam etmesine engel olunacağı da ortaya çıkmıştır.

\footnotetext{
${ }^{19}$ Şerafettin Turan, İsmet İnönü, Yaşamı, Dönemi ve Kişiliği, Ankara, Kültür Bakanlığı, 2000 , s. 307.

${ }^{20}$ Ulus, 30 Haziran 1950.

${ }^{21}$ Nihat Erim, "Partimiz ve Kurultayımız", Ulus, 30 Haziran 1950.

${ }^{22}$ Turan, s. 311-312.
} 
Kurultayda alınan kararlarla Parti Genel Sekreteri'nin artık Genel Başkan tarafından değil, kongre tarafından seçilerek göreve gelmesi ilkesi hayata geçirilmiştir. Parti Divanı üyelerinin sayısı 30 ile sınırlandırılmış ve bunların da seçimi kongrenin uhdesine bırakılmıştır. Parti Divanı'na da kongre sonrası bir dahaki kongreye kadar partinin yürüttüğü günlük faaliyetleri denetleme görevi verilmiştir. Parti politikalarının belirlenmesi de bundan böyle genel başkan, genel sekreter ve meclis grup başkanından oluşan bir heyetin sorumluluğuna geçirilmiştir. ${ }^{23}$

Yeni alınan bir diğer kararla partinin tüm yetkilerinin Kurultay'ın onayı ile belirlenmesi ve Genel Başkan Vekilliği biriminin kaldırılması kararlaştırılmıştır. ${ }^{24}$

Dönemin yapısı düşünüldüğünde parti içinde “devrim” denebilecek bu yapısal değişimler, Genel Başkan'ın iradesinin dışına çıkmayan partiye yeni bir hava getirecektir. Genel Sekreter'in de artık sözü geçen bir kişiye dönüşmesi, parti içi iktidarın bölünmesi demek olduğu için, artık bu makam bir önceki döneme oranla çok daha önem kazanmıştır.

Değişen usüller çerçevesinde Genel Sekreter seçimine geçildiğinde yedi adayın ortaya çıktığı görülmüştür. Yapılan oylamalarda ilk turda adaylardan hiçbirinin yeterli oyu alamaması sonucu ikinci tura geçilmiştir. Bu turda 485 oyun 224'ünü alan Kasım Gülek CHP'nin yeni Genel Sekreteri olarak seçilmiştir. Seçimlere geçilirken İnönü'nün desteklediği aday olarak bilinen, Ulus Gazetesi'nin yönetiminden sorumlu konumdaki Nihat Erim ise, ilk turda en çok oyu almasına rağmen diğer adayların Gülek lehine adaylıktan çekilecekleri ortaya çıkınca, kazanamayacağını görüp son turda aday olmayarak yarıştan çekilmiştir. ${ }^{25}$

Kurultay'da Ulus Gazetesi ile ilgili de bir karar alınacaktır. Buna göre CHP tüzüğünde Ulus ile ilgili bir değişiklik yapılarak "sarahat olmadıkça Ulus'un yayımları Partinin resmi temsilcilerine veya resmi heyetine atfolunamaz" ibaresinin gazetenin belli bir yerinde devamlı olarak yayımlanmasına karar verilmiştir. ${ }^{26}$

Görüldüğü gibi 8. Kurultay ile CHP için yeni bir dönem başlamıştır. Ancak başlayan bu dönemde partinin daha homojen bir yapıya kavuşmasından çok, bu yeni yapı, yeni tartışmalara olanak sağlayacak bir şeklin oluşmasına yol açacaktır. İnönü’nün tüm ağırllğ 1 ile karşı durduğu bir

\footnotetext{
${ }^{23}$ Ahmad, s. 111.

${ }^{24}$ Bila, 195.

${ }^{25}$ Turan, s. 312

${ }^{26}$ B.C.A. 490.01.151.167.2
} 
aday olan Kasım Gülek'in Genel Sekreter seçilmesi bile CHP yönetimi bazında bir sonraki dönemin sancılı geçeceğine delil niteliğindedir. Gülek genç ve dinamik bir politikacı olarak Erim'in parti içindeki yerini alacak, bundan sonraki dönemde DP iktidarı karşısında CHP muhalefetinin en güçlü ve popüler ismi olacaktır. ${ }^{27}$ Oluşan bu yeni dönemde Erim'in CHP yönetiminden uzak kalması Ulus Gazetesi'ndeki konumunu da etkileyip etkilemeyeceği Kurultay sonrasında oluşacak atmosfere göre şekil alacaktır.

CHP'nin 8. Kurultayında yaşanan gelişmeleri, Ulus Gazetesi, partinin yayın organı olması dolayısıyla detaylı biçimde okuyucularına aktarılmıştır. Ancak şunu söyleyebiliriz ki gazete, yaşananları, olumlu ya da olumsuz bir yorum yapmadan, tarafsız bir bakış açısıyla ortaya koymayı tercih etmiştir. Esasında Ulus Gazetesi'nin bu yansız tavrı, Nihat Erim'in Genel Sekreterlik yarışında yaşadığı yenilgiye rağmen, sonucu kabullenerek hareket etmesi, parti içi disiplinle de doğrudan alakalı olsa gerekir. İnönü, Kurultay kararlarına nasıl saygılı davrandıysa, gazetenin de CHP içindeki bu yeni yapılanmaya karşı herhangi bir tavır takınmadığını saptamak mümkündür. İnönü'nün Gülek'in Genel Sekreterliği'ni desteklememiş olması, CHP'nin üst düzey yönetiminde krizlerin çıkacağ 1 yorumlarına neden olmuştur. Ancak Ulus'un da tavrından anlaşılacağı gibi anlaşmazlıkların partinin içinde kalmasına, dışarıya pek sızmamasına gayret gösterilmiştir. Yukarıda da belirtildiği gibi Nihat Erim kurultayda oluşan yeni parti organlarında görev alamamış, bu sayede sadece Ulus Gazetesi'nin başında kalarak partide etkin olabileceği ortaya çıkmıştır. Buna karşılık Genel Sekreter Gülek, CHP'nin basınla ilişkilerini kendisi yürütmeye başlayacaktır. Üstü örtük rekabet içinde olmalarına "karşın", partide birlik ve beraberliği gözler önüne sermek için Erim ve Gülek, Kurultay sonrasında dostane bir tavır sergileyerek hatıra fotoğrafları çektireceklerdir. ${ }^{28}$

Böylece Kurultay'ın sonucunda Ulus Gazetesi'nin kurumsal kimliğinin nasıl şekilleneceği sorunu da ortadan kalkmıştır. Kongre yenilgisi sonrası Nihat Erim'in Ulus'un siyasi yöneticiliğini profesyonel olarak yerine getirmek için görevlendirilmesi ile gazetenin idari yapısında herhangi bir değişim yaşanmayacaktır. Yazı işleri müdürü Münir Berik, diğer idari çalışanlar ve yazar kadroları yine benzeri şekilde devam edecektir. Her ne kadar değiş̧en bir şey yok gibi görünse de gazete, özellikle maddi zorluklarla yüzleşmek durumunda kalacaktır. Altan Öymen'in anılarından anladığımıza göre gazetenin mali durumu pek parlak değildir. Ulus'ta işe başlamak için kongre sonrasını beklediğini bile getiren Öymen, "adam almayı değil adam

\footnotetext{
${ }^{27}$ Bila, s. 195-196.

${ }^{28}$ Toker, s. 74.
} 
çıkarmayı" düşünen gazeteye tereddüt içinde iş başvurusunda bulunduğunu yazmaktadır. ${ }^{29}$

\section{Ulus Gazetesi’nin Yeni Misyonu Üzerine Parti İçi Tartışmalar}

8. Kurultay ile yeni döneme yeni kadrolarla giren CHP için yeni bir muhalefet söyleminin ortaya çıkması kaçınılmazdır. Ulus Gazetesi bu dönemde muhalif söylemini her gün biraz daha şiddetlendirerek devam ettirmektedir. Nihat Erim'in önderliğinde Ulus'un giderek yapay bir sinir harbine dönecek olan söylemleri politik yaşama katk1 yapmaya başlayacaktır. ${ }^{30}$ Sözünü ettiğimiz yeni dönemde, Genel Sekreter olarak Parti içinde en önemli konumlardan birini işgal eden Kasım Gülek'in isteğiyle, 20 Temmuz 1950'de Ulus Gazetesi'nin konu olarak ele alınacağı bir toplantı tertip edilmiştir. Toplantıya Gülek ile Nihat Erim arasında gerçekleşen Genel Sekreterlik yarışının etkisi olduğu ve bu yarıșta galip gelen Gülek'in, Kurultaydaki rakibi olan Erim'e karşı bir tür güç gösterisi olarak bu toplantıyı kullandığı söylenebilir.

CHP içindeki konuyla ilgili "uzman" kişilere yollanan davette, bu toplantının amacını Ulus'un o günkü durumu ile gelecekte nasıl işlemesi gerektiği hakkında görüşmek ve tavsiye niteliğinde kararlar almak olduğunu belirten Gülek, bunun için bir komisyon kurulmasını ve bu komisyonda ortaya çıkacak fikirlerden faydalanılmasını ummaktadır. Bu toplantıya çağırılan isimler, Reşit Şemsettin Sirer, Dr. Sadi Irmak, Şefik Tugay, Yusuf Ziya Ortaç, Ferid Celal Güven, Ahmet Remzi Yüreğir, Kemal Turan, Ahmet Hamdi Selgil, Ahmet Şükrü Esmer, Mecdi Sadri Sayman, Nihat Erim, Ziya Arkant, Ethem İzzet Benice, Ferid Melen, Cavit Oral, Orhan Seyfi Orhon, Cemil Sait Barlas, Refik Ahmet Sevengil, Vedat Dicleli, İsmail Rüştü Aksal, Hakkı Tarık Us, Asım Us, Falih Rıfkı Atay, Nusret Safa Coşkun, Hıfzı Oğuz Bekata'dır.

Bunların arasında en ilgi çekenlerden biri Falih Rıfkı Atay olarak göze çarpmaktadır. Ulus Gazetesi'nin uzun yıllar başyazarlığını yapmış olan Atay, toplantıya mazeret bildirerek katılmamış, ancak yine de görüşlerini içeren 15 Temmuz tarihli bir raporu da CHP Genel Sekreterliği'ne iletmiştir. $^{31}$

$\mathrm{Bu}$ raporda yer alan Atay'ın görüşlerine kısaca bakacak olursak; yazara göre öncelikle Ulus'un bu yeni döneminde idare ve yazı kadrosu masraflarının yarıya yakın şekilde indirilmesi gerekmektedir. Gerçekten de

\footnotetext{
${ }^{29}$ Öymen, s. 510.

${ }^{30}$ Toker, s. 90.

${ }^{31}$ B.C.A., 490.01.1263.204..1
} 
1950 seçimleri öncesi Ulus çalışanlarının neredeyse tamamına yakınının maaşlarında artış olmuştur ${ }^{32}$. Ayrıca birçok partilinin gazetede yazı yazarak fazladan gelir sağlamakta oldukları bilinmektedir. Bunları Atay "ölü kadro" olarak değerlendirmekte ve çok geniş olduğundan dem vurmaktadır. Gazete kadrosunda tam zamanlı olarak çalışacak bir İngilizce tercümanın eksikliğine de vurgu yaptıktan sonra, başyazıların bir kişi tarafından ve durmaksızın yazılmasını eleştirmiştir. Bu usulün geri bir usul olduğunu ve bunun yerine imzasız başyazılara yer verilebileceğini belirtmiştir. Yazılan başyazıların ise yazarların uzmanlık alanları üzerine olmasına ve partinin prensiplerini doğru şekilde tahlil eden yazılar olmasına dikkat edilmelidir. Ancak başyazı yazacak kişilerin de çok artmaması gerektiği, iç politika, dış politika, ekonomi ve genel fikir yazılarını belli başlı kimselere havale edilebileceği düşüncesindedir. Bundan dolayı Ulus'un başında bu işleri idare edecek ve yazıları düzenleyecek bir "Directeur Politique" bulunmasını da önermiştir. Bu kişinin bağımsız hareket etmesinin gerekliliğine vurgu yapan Atay, parti divanına da burada görev düşmesi gerektiği görüşündedir. Buna göre bu yöneticinin görev süresi divan tarafindan her sene yenilenmeli ya da yerine bir başkası getirilmelidir.

Atay, bu raporunda bir başka konuya daha parmak basmıştır. O da Ulus'a ait olan eski makinelerin İstanbul'a getirilerek süratle ikinci bir gazetenin çıkarılmasıdır. ${ }^{33}$ Çıkarılacak bu gazetenin idare ve yazı işleri Ulus'la paylaşılarak yürütülmelidir. Böylece gazetenin en yüksek masraflarından biri olan şehir dışı muhabirliği işinin de, her iki gazete kadroları arasında karşı1ıklı olarak halledilmiş olacaktır. Ancak şunu da ilave etmektedir ki, İstanbul' da çıkartılması muhtemel olan gazete partiden daha serbest olmalı ve ayrı bir "Directuer Politique" ile yönetilmelidir. Fakat bu durum Parti Genel Başkanlığı ve Sekreterliği ile alakasız olacak demek de değildir.

Atay, son olarak bu yeni dönemde Ulus ve kurulması gerektiğini düşündüğü gazetenin partiden para almadan, hatta partiye para kazandıracak şekilde hareket etmesi gerektiğine de vurgu yapmıştır. Raporun sonunda ise "içinde bulunduğumuz muhalefet hayatı içinde bunu yapamamak

\footnotetext{
${ }^{32}$ B.C.A., 490.01.125.166.1

${ }^{33}$ Falih Rıfkı Atay, çıkarılması için görüş bildirdiği İstanbul'daki gazeteyi daha sonra Dünya Gazetesi adıyla çıkartmaya başlayacaktır. 1954'de Falih Rıfkı'dan Ulus'a ait olan bu eski matbaası yok pahasına kendisine satıldı ğı gerekçesiyle CHP mallarıyla birlikte bu matbaanın da devredilmesi istenecektir. Bkz. Nuran Yıldız, "Demokrat Parti İktidarı (1950-1960) ve Basın,” Ankara Üniversitesi Siyasal Bilgiler Fakültesi Dergisi, C. 51. Say1: 1, s. 501.
} 
sanatsızlıktan başka hiçbir sebepten izah edilemez. Gazete bir gazeteci işidir. Bir mizaç ve meleke meselesidir" demektedir.

Görülüyor ki eski başyazarın genel olarak CHP'nin propaganda usullerinin değişmesi ve özelde de Ulus'un gerçek gazeteciler tarafindan işletilmesi gerektiği üzerine eleştirileri vardır.

Falih Rıfkı'nın katılmadığı, Gülek'in başkanlığında yapılan ve iki gün süren toplantılarda yukarıda belirtilen isimler, Atay'ın Ulus özelinde CHP'nin basın yoluyla gerçekleştireceği propagandaların nasıl olması gerektiği üzerindeki görüşlerini paylaşmışlardır. Toplantı tutanaklarından anlaşıldığına göre, Atay'ın sözünü ettiği, İstanbul'da partiye bağlı bir gazetenin çıkartılması konusu uzun uzadıya tartışılmış, eski baskı makinelerinin İstanbul'da bir binada yeniden kurulması ve bir matbaanın ticari bir zihniyetle açılması kabul edilmiş ancak İstanbul'da yeni bir günlük gazete çıkartılması reddedilmiştir. Bu konuda Nihat Erim'in ve Hakkı Tarık Us'un aleyhte görüş bildirmeleri etkili olmuştur. ${ }^{34}$

Toplantıda zaman zaman Ulus Gazetesi'nin yapısı da eleştirilmiştir. Bu eleştiriyi yapanlardan biri de Orhan Seyfi Orhon'dur. Orhon'a göre Ulus'un partiden bağımsız kendine göre bir politikası vardır. İstediğini yazıp istemediğini yazmadığını, istediğine yazdırıp istemediğine yazdırmadığını, bu durumun anlaşılmasının güç olduğunu belirtmiştir. Ayrıca Hüseyin Cahit Yalçın'ın ülke dışından (tedavi amacıyla gittiği Cenevre'den) ortamdan uzak şekilde çok yıkıcı yazılar yazdığına ve tehlike arz ettiğine, uzun süredir kalemini bu şekilde kullanarak taraftar değil aleyhtar kazanmış olduğuna ve bu yüzden de Ulus'un da antipatik olduğuna dikkat çekmiştir. Bu duruma çözüm olarak Hüseyin Cahit'in yerine halka daha sempatik gelecek bir kişinin bulunmasını önermiştir.

Dr. Sadi Irmak da bir gazetenin her şeyden önce bir gazete olmas1 gerektiğini, "beylik bir gazetenin yürüyemeyeceğini”, Ankara'nın içinde bulunduğu ortamın Ulus tarafindan tam olarak verilmesinin ve gazetenin ahenkli bir şekilde çalışmasının doğru olacağını eleştirel bir dille belirtmiştir. Hüseyin Cahit'in iyi bir "dövüş" ve polemik adamı olduğuna şüphe duymadığını, ancak her gün başyazı yazmasının doğru olmadığı, diğer yazarların da objektif yazılarının Ulus'un baş sütununda yer alması gerektiğini de eklemiştir.

Hüseyin Cahit'in başyazı yazması konusunda, Ahmet Şükrü Esmer, tam aksi bir görüşle deneyimli yazarı savunarak karşılık vermiştir. Esmer'e göre

\footnotetext{
${ }^{34}$ B.C.A., $490.01 .1263 .204 . .1$
} 
başyazarlığın belli başlı bir iş olduğu sabah çıkacak olan bir başyazının şartlar tarafindan belirlendiği görüşünü dile getirmiştir.

Nihat Erim ise eleştirilere cevaben, Ulus'un sayfalarında amatörlerin yazmasına izin verilemeyeceğine, haftanın yedi günününde kimin nasıl yazılar yazacağının da belirlenmiş olduğuna, herhangi bir boşluğun olmadığına işaret etmiş, ayrıca "gazete, gazete mi olacak yoksa partinin kürsüsü mü, her eli kalem tutan partili burada fikirlerini yazsın. Tabiatıyla buna imkân yoktur. Gazete kime emanet ediliyorsa bütün bu işin organizasyonu ve sevk ve idaresi ona bırakılır" diyerek tüm eleştirilerin bir anda son bulmasını sağlamıştır. Toplantıda bulunan Genel Sekreter Gülek dâhil herkes biliyordu ki, İsmet İnönü'nün atadığı Erim, Ulus'un tek patronu konumundadır. Ve o da son sözünü söylemiş̧tir. Bu ortamda toplantıya devam edilse de, bundan sonraki oturumlarda önemli bir durum ortaya çıkmamıştır. Bu sayede Erim'in, Ulus'daki konumunu sürdürdüğü ve parti içinden gelebilecek eleştirilerin de önünün alındığg düşünülebilir.

Yaşanan bu gelişme sonrası Erim'in etkinliğinin arttığı görülse de gazetenin partiden tam bağımsız şekilde hareket ettiği düşünülmemelidir. Örneğin yeni gelen bir yazarın gazetede yazı yazma talebi, önce CHP Genel Sekreterliğine iletilir, uygun bulunması durumunda bu konu Ulus İdare Komitesinde görüşülür, onların alacağı tavsiye niteliğindeki karar ise yeniden CHP Genel Sekreterliği'ne bildirilerek işlem gerçekleşirdi. ${ }^{35} \mathrm{Bu}$ uygulama yeni dönemde de devam edecektir.

Yeni dönemde Ulus Gazetesi'nin yaşatılabilmesi için bir takım ekonomik tedbirler de alınmıştır. Muhalefete geçişle beraber, başta devlet ilanları gibi birçok maddi kaynağından mahrum kalan Ulus Gazetesi, Halkodalarıyla, köy ve bucaklardaki Halkevlerine 11 Ağustos 1950 tarihinden itibaren nüshalarını "ücretsiz olarak göndermeme" kararı almıștır. Gazetenin yıllık abonelik ücreti ise 20 lira olarak belirlenmiştir. ${ }^{36}$ Günlük gazetenin 10 kuruş olduğu bir ortamda yine de uygun olduğu düşünülebilecek olan bu yeni ücretlendirme Ulus'un artık kendi imkânları ile yaşaması gerektiğini gözler önüne sermesi bakımından önemlidir. Ancak alınan bu karara rağmen, ülkenin neredeyse her yerindeki CHP örgütlerinin partinin Genel Sekreterliği ile yaptıkları yazışmalarda, Ulus'un yörelerindeki Halkevlerine bedelsiz bir şekilde gelmesi için yoğun talepleri olduğunu da belirtmek gerekir. ${ }^{37}$

\footnotetext{
${ }^{35} \mathrm{Bu}$ duruma güzel bir örneği dönemin 16 Şubat 1951 tarihli, Ordu Milletvekili Yusuf Ziya Ortaç'ın Ulus'ta yazı yazma isteği çerçevesinde yürütülen yazışmalarda görmek mümkündür. Bkz. B.C.A., 490.1.0.0.1252.169..1

${ }^{36}$ B.C.A., 490.01.11.57.9

${ }^{37}$ B.C.A., 490..0.0.1263.204.1
} 
1950 seçimlerinin ardından, yaşanan Kurultaydan yeni bir örgütlenme anlayışıyla çıkan CHP'nin, milletvekillerinin "az ve etkisiz" olması dolayısıyla, muhalefetin Meclis içinde etkin biçimde işletilebilmesine hayli güçleşmiştir. Bu durum CHP muhalefeti için Ulus Gazetesi'ni son derece stratejik bir konuma getirmiştir. Ulus'un öneminin artmas1, Erim'in de parti içindeki önemini de arttırmıştır. Kimi iddialara göre Erim, CHP politikalarının tek yürütücüsü konumuna gelmiştir. Cüneyt Arcayürek anılarında Erim'in partiye ve politikalarına yönelik yönlendirmelerinin miktarını ve bunların biçimini Ulus'ta saptadığını, sonradan parti toplantılarında bunların resmileştiğini belirtmektedir. Bunun nedeninin İnönü'nün Erim'e çok güvenmesinden kaynaklandığını belirten yazara göre, bir konu hakkında CHP'nin tavrıyla ilgili olarak İnönü önce Erim'e görüşlerini aktarıyor, Erim bunu hem CHP ileri gelenleriyle hem de gazetede paylaşıyor, ardından konu İnönü'ye intikal edince Genel Başkan'dan da onay çıkıyor ve bu politika uygulanıyordu. ${ }^{38}$

Görüldüğü gibi Ulus Gazetesi'nin seçimlerden hemen sonra yaşadığ1 yeniden yapılanma süreci, sadece Ulus çerçevesinde değerlendirilemeyecek kadar önemlidir. Partinin 8. Kurultayında yaşadığı mağlubiyete rağmen kısa vadede Nihat Erim'in değerlendirmelerini önemli kılmıştır. Hem gazetenin politik çerçevesini anlamakta hem de CHP'nin muhalefetinin unsurlarını değerlendirmekte değerli birer örnek teşkil etmesi bakımından önemsenmesi gereken görüşleri ile Erim, 1950 seçimleri ile oluşan ortamı, her zaman "bir tür kaza" olarak değerlendirmiş ve DP'nin iktidarını ulusal bir yanılma olarak görmüştür. $\mathrm{Bu}$ nedenle 1950-1954 arasında sert bir muhalefet yürütmekte kararlı olmuştur. Eleştiri mekanizması, özellikle Başbakan Adnan Menderes'in şahsına yönelik olmuş hatta bu eleştiriler neredeyse düşmanlığına varmış ve bu durum CHP politikalarını da etkilemiştir. Metin Toker'in anılarında yer alan şu olayı bu duruma örnek olarak verebiliriz ${ }^{39}$ :

“...DP henüz yolunu ararken, Menderes bir basin toplantist tertiplemiştir. O sırada Ulus'u Nihat Erim idare ediyor, başyazılarını Hüseyin Cahit Yalçın yazıyordu. Toplantıya Ulus temsilcilerini de çağırmışlardır. Kim gidecektir? İsmet Pașa ve Genel idare kurulu hem Erim'in hem Yalçın'ın gitmesini istemişlerdir. Bu bir 'buz çözülmesi' de olacak Nihat Erim'in sonrada savunmasını yapacağl 'medeni

\footnotetext{
${ }^{38}$ Cüneyt Arcayürek, Arcayürek Açıklıyor, Yeni İktidar Yeni Dönem 1951-1954, Kitap Ankara, Bilgi Yayınevi, 1985, s. 110.

${ }^{39}$ Metin Toker, Demokrasimizin İ́smet Paşa'lı Yılları, DP Yokuş Aşağı, 1954-1957, Ankara, Bilgi Yayınevi, 1991, s. 53-54.
} 
münasebetler'in örneğini teşkil edecektir. İsmet Paşa bu isteği Hüseyin Cahit Yalçın'a söylemiş, Yalçın 'Peki, giderim' demiştir. Fakat Nihat Erim 'Ben gitmem' diye tutturmuştur. Israr, rica, bizzat Ismet Paşanin telkinleri... Hayır, Erim Nuh deyip peygamber dememektedir.Ismet Paşa araya Şemsettin Günaltay'ı da koymuş 'Bari sen git, bir de sen söyle , ısrar et..' demiştir. Fikrini şöyle anlatmıştır:

'Bu hava memleket için lüzumlu havadır. Devam etmesinde hem demokrasimiz için, hem partimiz için fayda vardır. Toplantiya katılsin!'

Fakat hiçbir şey para etmemiş ve Nihat Erim toplantıya gitmemiştir."

Ulus'un başında olmanın ne derece önemli olduğuna dair bir ipucu veren bu anıdan da anlaşıldığı gibi Nihat Erim, CHP Genel Başkanı İnönü'ye rağmen zaman zaman muhalifliği aşırıllı̆̆a da çekebilmiştir. ${ }^{40}$

Nihat Erim'in başkanlığında Ulus'un da genel politikası, 1950-1954 arasında bu şekilde olmuştur. Erim'in yazarlara her zaman fenalıkların hepsinin müsebbibi olarak Adnan Menderes gösterilecek talimatı verdiği bilinmektedir. Bu yüzden Menderes'in özel hayatını da yakından takip etmek istemiş ve peşine özel fotoğrafçılar bile takmıştır ${ }^{41}$.

40 Menderes'e karşı muhalefet çok yoğun işlerken, ender de olsa Ulus sütunlarında Cumhurbaşkanı Celal Bayar'ın da eleştirildiğine rastlanmaktadır. Yapılan usulsüzlükler ile Toprak Ofisi'nin önemli zararlara uğradığı üzerine yapılan bir haberde silolara ait 2.5 milyon liralık mekanik tesisler ihale edilirken "bazı nüfuzlu şahıslar"ın himaye edildikleri iddia edilmiştir. Ulus'ta yer alan bu haber üzerine her ne kadar haber metninde adı geçmese de Celal Bayar'ın rahatsız olduğu ve Adnan Menderes'e yolladığı bir şifreli telde rahatsızlığını şu şekilde dile getirdiği görülmektedir: (bkz. B.C.A., 30..1.0.0.1.7..15)

"Ulus Gazetesinin onbeş nisan salı günü nüshasinda Toprak Ofisde önemli başlıklı yazısında nüfuzlu şahsiyetlerin himaye ettikleri iddiası kaylt olunarak yolsuz bir ihalenin yapıldı ̆̆ ve bu iş de Feyyaz Söker ve Abdurrahman Ağaoğlu'nun isimleri geçtiği görülmüşı̈̈r. Böyle bir işin ne evvelinden ve ne de nihayetinden habersiz olmadığı ve olamayacă̆l aşikardır. Ancak bu

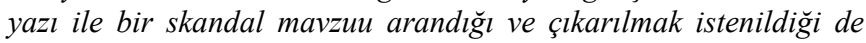
meydandadır. Meseleyi bizzat tetkik eder eğer küçük bir usulsüzlük ve dürüst olmayan bir hareket gördüğ̈̈nüz takdirde ihalenin iptalini rica ederim"

${ }^{41}$ Toker, DP Yokuş Aşağı , s. 54, 


\section{Sonuç}

14 Mayıs 1950'de CHP'nin iktidarı serbest seçimleri ile kaybetmesi sonras1 partinin yayın organ1 olan Ulus Gazetesi'nde yeniden yapılanma yaşanmıştır. Öncelikle 27 yıllık bir iktidar partisinin "iktidarın sesi" olarak yayın yapan gazetesi olmaktan çıkıp, artık iktidarı eleştirecek bir söyleme geçmektedir. Görülüyor ki bunu yaparken öncelikle "geçmişin savunusu" ve "gelecekten beklentiler" çerçevesinde yaptığı yayımlarla gazete bu geçiş sürecine adapte olmaya çalışmıştır. Ancak söylemsel düzeyde yaşanan bu değişime karşın, Ulus'un gazetecilik anlamında teknik bir değişim yaşamadığııı da saptamak gerekir. Örneğin Hüseyin Cahit Yalçın'ın 1948'den beri sürdürdüğü başyazarlık, bu dönemde de devam etmiştir. Ancak, artık iktidar olanaklarını yitiren gazetenin mali yönden zorluklar yaşaması da bir gerçek olarak karşımıza çıkacaktır.

$\mathrm{Bu}$ yeniden yapılanma sürecinde belki de en radikal değişim tam yetkili olarak Nihat Erim'in gazetenin başına geçmesiyle yaşanmıștır. Erim'i başa geçmesi Genel Başkanlığ 1 aktif olarak yeniden üstlenen İsmet İnönü'nün desteği ile olduğu, buna karşın İnönü'nün bu kararında eleştirildiği de görülmüş̧ür. $\mathrm{Bu}$ eleştiriler hem Erim'in siyasi kimliğinden hem de mesleğinin gazetecilik olmamasından kaynaklandığı söylenebilir. Erim, bu geçiş sürecinde sadece Ulus'un başına geçmekle kalmamış, aynı zamanda CHP'nin yönetim yapısının da değiştiği 8. Kurultay'ında partideki yetkileri arttırılan Genel Sekreterlik görevine de aday olmuştur. Bu adaylığı Ulus'ta yaşanan değişime paralel olarak CHP'nin parti içi örgütsel yapısının da değişime uğradığı süreçte yaşanmış olması anlamlıdır. Her ne kadar seçilemese de kurultay sonrası İnönü'nün desteğiyle Ulus Gazetesi'deki konumu devam etmesi Erim'i parti içindeki önemini yitirmemesi sonucunu doğurmuştur. Böylece denebilir ki, seçimlerin hemen ardından gazetede yaşanan yönetim değişikliği Kurultay sonrasında da onaylanarak devam etmiştir.

$\mathrm{Bu}$ dönemde özellikle TBMM'de güç kaybetmiş olan CHP'nin muhalefet ederken kullanacağı en önemli aygit olarak Ulus Gazetesi'nin zaman içinde sivrilmesi Erim'in parti içinde “önemini” arttırmıştır. CHP'nin mallarının devletleştirilmesi aşamasında 14 Aralık 1953'de son kez Ulus adıyla çıkana kadar Erim'in gazetedeki, dolayısıyla da parti içindeki etkisi artarak devam etmiştir. Bu tarihten sonra da Erim "parti gazetesi" misyonunu, bizzat sahip olduğu "Yeni Ulus" ve ardından da "Halkçı" adıyla çıkarmış olduğu gazetelerle sürdürecektir. 


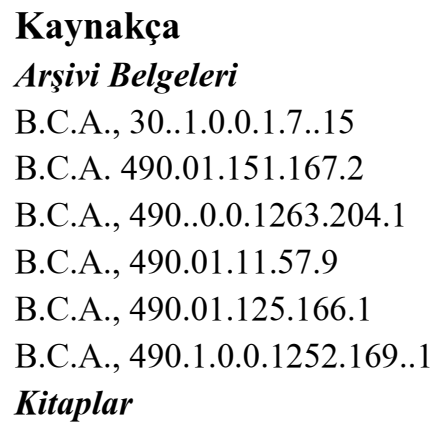

Ahmad, Feroz, Demokrasi Sürecinde Türkiye (1945-1980), Çev. Ahmet Fethi, İstanbul, Hil Yayın, 1996

Arcayürek, Cüneyt, Arcayürek Açıklıyor, Yeni İktidar Yeni Dönem 1951-1954, Kitap Ankara, Bilgi Yayınevi, 1985.

Barutçu, Faik Ahmet, Siyasi Anılar, İstanbul, Milliyet Yayınları, 1977, s. 434-435.

Bila, Hikmet, Sosyal Demokrat Süreç Iç̧inde CHP ve Sonrası, Milliyet Yayınları, 2. bask1 1987.

Coşkun, Süleyman, Türkiye'de Politika (1920-1995), İstanbul, Cem Yayınevi, 1995.

Erim, Nihat, Günlükler 1925-1979, C.I, İstanbul, YKY, 2005.

Güngör, Süleyman, Muhalefette Cumhuriyet Halk Partisi, Ankara, Alternatif Yayınlar1, 2004.

Konyar, Hürriyet, Ulus Gazetesi, CHP ve Kemalist İlkeler, İstanbul, Bağlam Yayınları, 1999

Öymen, Altan, Değişim Yılları, İstanbul, Doğan Kitapları, 2004.

Toker, Metin, Demokrasimizin İsmet Paşa'lı Yılları, DP Yokuş Aşă̆l, 1954-1957, Ankara, Bilgi Yayınevi, 1991. ,DP'nin Altın Ylllarl, Ankara, Bilgi Yayınevi 1991.

Turan, Şerafettin, Ismet, Inönü, Yaşamı, Dönemi ve Kişiliği, Ankara, Kültür Bakanlığg1, 2000.

\section{Makaleler}

“B.Millet Meclisi Bugün Çalışmalara Başlıyor” Ulus, 22 Mayıs 1950,

"Demokrat Parti İktidarı Fiilen Ele Aldı", Ulus, 23 Mayıs 1950.

Erim, Nihat, "Demokrasi Yolunda Bir Oluşun Hikayesi XI”, Ulus, 5 Haziran 1950. , "Partimiz ve Kurultayımız”, Ulus, 30 Haziran 1950.

Ulus, 30 Haziran 1950.

Yalçın, Hüseyin Cahit, "Yeni İktidar”, Ulus, 22 Mayıs 1950.

, “Büyük İsmet İnönü”, Ulus, 16 Mayıs 1950.

Yıldız, Nuran, "Demokrat Parti İktidarı (1950-1960) ve Basın,” Ankara Üniversitesi Siyasal Bilgiler Fakültesi Dergisi, C. 51. Sayı: 1 